\title{
Jezus Chrystus Arcykapłan
}

Kapłaństwo ${ }^{1}$ było związane z dziedziczną klasą żydowską, której przypisane były specyficzne funkcje ofiarnicze. Istotnym zadaniem kapłana (kohen) była posługa w rytach świątynnych, w których spełniał on rolę «sługi pałacowego» w ziemskim przybytku boskiego Króla... Zgodnie z tradycją, kapłani wywodzą się z jednego rodu/rodziny pokolenia Lewiego. Według Tory są oni potomkami Aarona; w Księdze Proroka Ezechiela są oni zwani „synami Sadoka”. Jak poświadczają Wj 29 i Kpł 8-9, kapłaństwo zostało ustanowione, gdy budowany był przybytek. Kapłanami zostali Aaron i jego czterej synowie (z czasem także jego wnukowie). Kapłani byli konsekrowani przez siedmiodniową ceremonię inwestytury: przywdziewali szaty kapłańskie, pozostawali w przybytku, Mojżesz zaśskładał ofiary, z których otrzymali oni po raz pierwszy należne im przywilejem części (mattenot kehunnah) ${ }^{2}$. Przywileje jednak pierwszych kapłanów zostały zmniejszone, gdy dwaj synowie Aarona, Nadab i Abihu, zostali skazani na karę śmierci za ich grzech (Kpł 10, 1-5). Najważniejsze i najświętsze ryty mogły być spełniane jedynie przez arcykapłana.

Po takim wstępie możemy rozpocząć rozważanie funkcji arcykapłańskiej Jezusa Chrystusa, o której informacja po raz pierwszy pojawia się w Nowym Testamencie dopiero w Hbr 2, 17: „Dlatego musiał się upodobnić pod każdym względem do braci, aby stał się miłosiernym

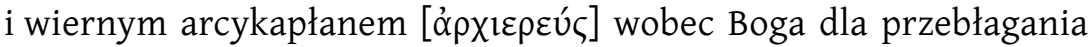
za grzechy ludu". Brak wcześniejszych informacji (Ewangelie, Corpus

${ }^{1}$ Por. B. Schwartz, Priesthood, [w:] The Oxford Dictionary of Jewish Religion, editors in chief R. J. Werblowsky, R. Wigoder, New York-Oxford 1997, s. 544-545; M. Haran, Priests and Priesthood, [w:] Encyclopedia Judaica, vol. 16, editor in chief F. Skolnik, executive editor M. Berenbaum, Detroit-London 2007, s. 513-523; por. Kohanim, [w:] Sara E. Karesh, Mitchell M. Hurvitz, Encyclopedia of Judaism, New York 2006, s. 277; R. Hayward, Priesthood, Temple(s), and Sacrifice, [w:] The Oxford Handbook of Biblical Studies, edited by J. W. Rogerson, J. M. Lieu, Oxford 2006, s. 319-350.

${ }^{2}$ Por. B. Schwartz, Priestly privileges, [w:] The Oxford Dictionary of Jewish Religion, dz. cyt., s. 545. 
Paulinum) nakazuje wręcz dokładne przyjrzenie się kontekstowi teologicznemu w Hbr, by zrozumieć istotę i godność kapłaństwa Chrystusa i kapłaństwa Chrystusowego.

\section{Terminologia}

\section{Stary Testament - Tekst Masorecki}

Na kartach Starego Testamentu pojawia się termin hebrajski, który wskazuje na pewną już hierarchiczność, a przynajmniej na rozróżnienie funkcji arcykapłana od innych kapłanów. W rzeczy samej znajdujemy

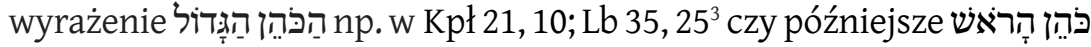
w $2 \mathrm{Krl}$ 25, 18; 2 Krn 19, 11; Ezdr 7, 5 (o Aaronie) ${ }^{4}$, czy wreszcie rzadkie

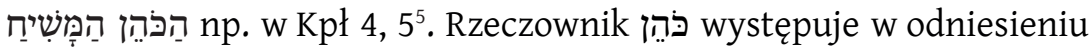
do kapłaństwa lewickiego jedynie w Pwt i kolejnych księgach (463 razy w tekście masoreckim). Pojawia się jednak wcześniej w związku z osobą i posługą Melchizedeka $(\mathrm{Rdz} 14,18)$ i odnosi się do funkcji ofiarniczej.

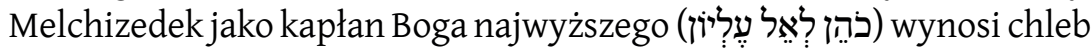

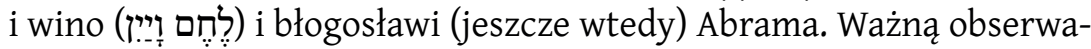
cją w tym punkcie jest fakt, że nie istnieje jeszcze kapłaństwo lewickie, a Melchizedek nazwany jest właśnie terminem przypisywanym od czasów judaizmu rabinicznego tylko kapłaństwu lewickiemu'.

${ }^{3}$ Wyrażenie to występuje 21 razy w tekście masoreckim; kompletna lista w porządku kanonu hebrajskiego: Kpł 21, 10; Lb 35, 25. 28²; Joz 20, 6; $2 \mathrm{Krl} \mathrm{12,} \mathrm{11;} \mathrm{22,} \mathrm{4.} \mathrm{8;} \mathrm{23,} \mathrm{4;} \mathrm{Ag}$ 1, 1. 2. 14; 2, 2. 4; Za 3, 1. 8; 6, 11; Neh 3, 1. 20; 13, 28; 2 Krn 34, 9.

${ }^{4}$ Wyrażenie to występuje 8 razy w tekście masoreckim; w porządku kanonu hebrajskiego: $2 \operatorname{Krl}$ 25, 18; Jer 52, 4; Ezdr 7, 5; 1 Krn 27, 5; 2 Krn 19, 11; 24, 11; 26, 20; 31, 10.

${ }^{5}$ Wyrażenie to występuje 4 razy w tekście masoreckim i tylko w Księdze Kapłańskiej 4, 3. 5. 16; 6, 15; ostatnia z tych referencji odnosi się do najwyższego kapłana, który ma zastąpić na stanowisku Aarona, wcześniejsze natomiast znajdują się w kontekście składanych ofiar za grzechy samego arcykapłana (pierwsze dwie referencje) oraz za całą społeczność Izraela.

${ }^{6}$ Por. G. Granerød, Melchizedek in Hebrews 7, „Biblica“ 90 (2009) s. 188-202. 
Stary Testament - Septuaginta

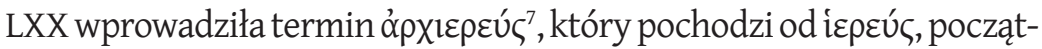

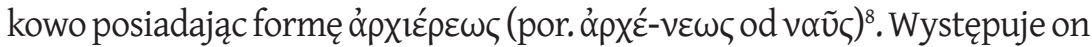
44 razy w LXX, ale tylko 3 razy w tekstach mających odpowiedniki w Biblii hebrajskiej (Kpł 4,3; Joz 22, 13; 24,33) ${ }^{9}$. Wszystkie pozostałe użycia terminu

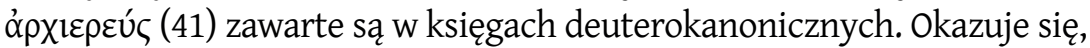
że LXX posiada inne wyrażenia, które odzwierciedlają mnogość określeń

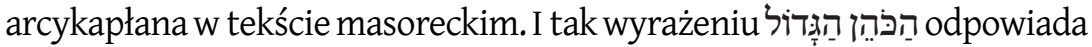

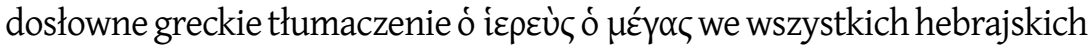

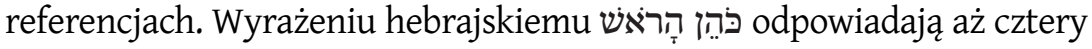

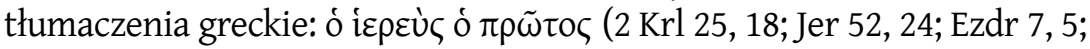

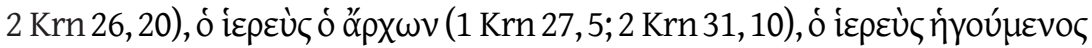

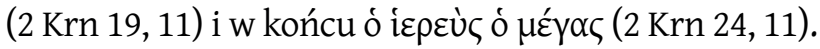

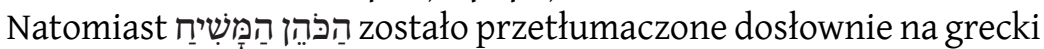

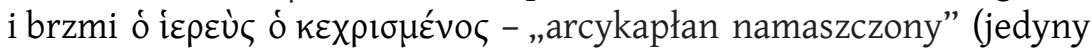
przypadek w Kpł 4, 3 - participium passivum perfectum nom. sing.

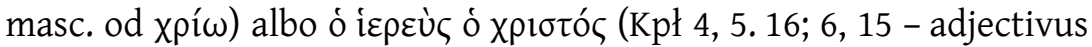
nom. sing. masc., to tłumaczenie jest gramatycznie równorzędne, gdyż jest przymiotnikiem jak jego hebrajski odnośnik).

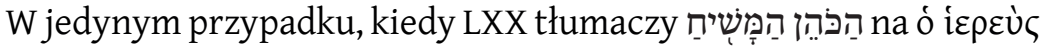

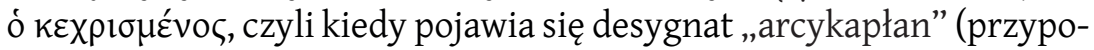
mnijmy, że tylko on był namaszczany), w tłumaczeniu Biblii Tysiąclecia czytamy: ,jeżeli ten grzech popełni namaszczony kapłan, tak że jego wina spada na lud, to złoży Panu jako ofiarę przebłagalną za grzech,

${ }^{7}$ Termin ten pojawia się po raz pierwszy u Herodota na określenie dziedzica lub głównego kapłana starożytnego Egiptu i ma na myśli drugi urząd po faraonie - por.

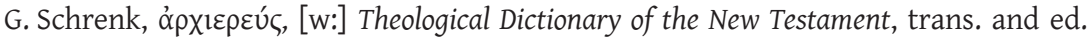
G. W. Bromiley, t. 3, Grand Rapids 1966, s. 266.

${ }^{8}$ Por. F. Blass, A. Debrunner, A Greek grammar of the New Testament and other early

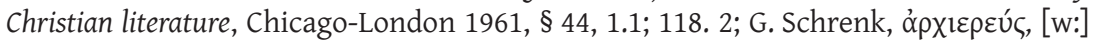
Theological Dictionary of the New Testament, dz. cyt., t. 3, s. 265.

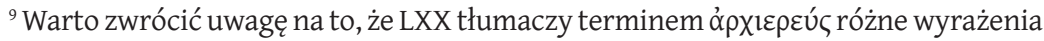

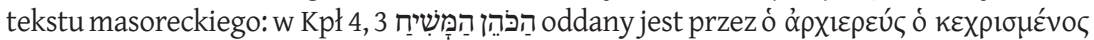

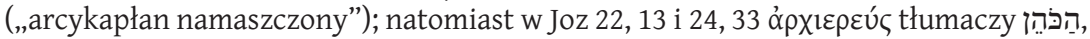
przy czym w 24, 33 termin hebrajski występuje tylko w kilku manuskryptach hebrajskich oraz w wersji syryjskiej i arabskiej (por. aparat krytyczny do tekstu w Biblia Hebraica Stuttgartensia, editio secunda emendata, Stuttgart 1984, s. 398). 
który popełnił, młodego cielca bez skazy". Posiadamy więc kontekst ofiary i komunikowania winy z arcykapłana na lud. Czy można przypuszczać, że określenie ó í by przedstawić możliwość komunikowania efektu ofiary wysłużonej przez arcykapłana Jezusa Chrystusa dla ludu?

Kontekst historyczny zatraty sensu posługi i roli arcykapłana

Od Oniasza II (do 175 roku przed Chrystusem) przez prawowitego Oniasza III, który wyruszył do Egiptu i w Leontopolis otrzymał pozwolenie na budowę świątyni ${ }^{10}$, dopiero w 153 roku przed Chrystusem pojawia się nowy arcykapłan i jest nim Jonatan Hasmoneusz, nie sadokita, ale z rodu kapłańskiego. Do czasów Arystobula w ciągu 116 lat było 8 arcykapłanów. Od 37 roku przed Chrystusem do 70 po Chrystusie (106 lat) było 28 najwyższych kapłanów, z czego 25 nie pochodziło z rodów kapłańskich. Znamy kilka takich rodów: Boethus, Annasz, Fiabi, Kamith.W 67 roku po Chrystusie, gdy zeloci zdobyli Jerozolimę, ogłosili wszyskie te rody jako bezprawnie piastujące urząd, a nakazali wybierać losowo arcykapłanów spośród Sadokitów. W czasach Jezusa powyższy chaos zniszczył rolę i wpływy arcykapłana, uzależniając go od kaprysu politycznego, symonii i współzawodnictwa, dodatkowo wzrost władzy i autorytetu faryzeuszy i skrybów dokończył dzieła pomniejszenia roli arcykapłana, choć pozostawał on najwyższym religijnym przedstawicielem narodu żydowskiego ${ }^{11}$.

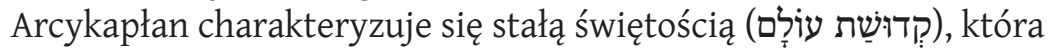
nawet w przypadku choroby nie odbierała mu możliwości składania ofiar, co było niemożliwe w przypadku zwykłych kapłanów. Śmierć arcykapłana uwalniała zabójców od zemsty: „Społeczność zabezpieczy go przed zemstą mściciela krwi i przyjmie go z powrotem do miasta ucieczki, gdzie się schronił, i będzie tam przebywał aż do śmierci arcykapłana, który jest namaszczony olejem świętym" (Lb 35, 25).

${ }^{10}$ Przetrwała ona do 73 roku po Chrystusie.

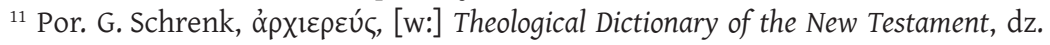
cyt., t. 3, s. 268. 
Arcykapłana charakteryzował również specjalny strój składający się z 8 części. Szaty arcykapłana gładzą różne grzechy, w czasach Jezusa były w posiadaniu Rzymian ${ }^{12}$.

Zgodnie z Miszną arcykapłan rozpoczynał liturgię Jom Kippur tygodniowym sprawowaniem liturgii, zwracając szczególną uwagę na swą czystość rytualną ${ }^{13}$.

\section{Strój kapłański i arcykapłański}

Kapłani nosili 4-częściowy strój liturgiczny: wykonane z białego lnu tunika, mitra (czapka), pas oraz lniane spodnie (Wj 28, 40-43). Strojów tych nie wolno było nosić na dziedzińcu zewnętrznym (Kpł 6, 4), a po liturgii należało oddać je do świętych pomieszczeń (Ez 42, 14; 44, 19) ${ }^{14}$. Kapłani i arcykapłan nie nosili żadnych butów (Wj 3, 5; Joz 5, 15; ExRb 2,6) ze względu na świętość miejsca.

Arcykapłan dodatkowo przywdziewał cztery inne symboliczne elementy wymagane przez ofiarę wieczystą (tamid - Kpł 28, 6-38), stąd szaty arcykapłańskie posiadały 8 części: cztery wspomniane wyżej oraz efod, pektorał, suknię i diadem. Istnieje również taki nakaz w Mishnie Joma 7, 5. Ciekawostką tutaj jest fakt, że jedynie arcykapłan miał szaty wykonane z mieszanki lnu i wełny, czyli włókien roślinnych i zwierzęcych pomieszanych ze sobą - jest to ściśle zabronione innym (Kpł 19, 19; Pwt 22, 9-11). Dodatkowe elementy stroju świadczyć miały o charakterze królewskim (złoto, kolor niebieski, purpura i korona-diadem), a połączone z mitrąi olejem ustanawiającym najwyższego kapłana (Wj 29,7), nadawały mu królewski wygląd i godność. Inną ciekawostką jest to, że księdze Ezechiela znane są tylko 4 pierwsze elementy wspólne wszystkim kapłanom i wykonane jedynie z lnu, co mogłoby świadczyć

${ }^{12}$ Działo się tak od Heroda Archelaosa (około 4 rok przed Chrystusem) do Klaudiusza (45 rok po Chrystusie).

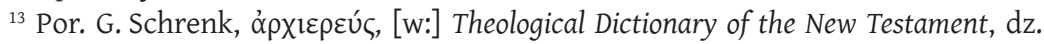
cyt., t. 3, s. 269.

${ }^{14}$ Por. B. Schwartz, High Priest, [w:] The Oxford Dictionary of Jewish Religion, dz. cyt., s. 322; B. Schwartz, Priestly Vestments, [w:] The Oxford Dictionary of Jewish Religion, dz. cyt., s. 546; M. Haran, Priestly Vestments, [w:] Encyclopaedia Judaica, dz. cyt., t. 16, s. 511-513. 
przynajmniej o braku wskazówki o istnieniu instytucji najwyższego kapłana w tamtych czasach ${ }^{15}$.

Pierwszym z dodatkowych elementów stroju arcykapłana był efod zewnętrznie prezentujący się jak fartuch, przywdziewany na tunikę, z dwoma kamieniami onyksowymi na ramionach, na kamieniach wyryte były imiona synów Izraela (po sześć imion na ramieniu według porządku urodzenia). Efod wykonany był z bisioru, karmazynu i nici złotych oraz fioletowej i czerwonej purpury. Na efod zakładany był hoszen, czyli pektorał (albo ryngraf) decyzji (wyroczni) wykonany z tych samych materiałów co efod, był on jednak kwadratowy o długości jednej piędzi (około 20-22 cm). Zawierał on cztery rzędy drogich kamieni, każdy z wyrytym imieniem synów Izraela. W pektorale zaś znajdowały się kamienie urim i tummim. Dwoma pozostałymi elementami stroju arcykapłana były: niebieska suknia, której skraj obszyty był ozdobnymi jabłkami granatu oraz złotymi dzwoneczkami, i złoty diadem. Arcykapłan, gdy wchodził i wychodził do Świętego Świętych, miał być słyszany przez Boga, to zaś miało służyć jako skuteczna pomoc w ratowaniu życia arcykapłana przy spotkaniu z Bogiem (Wj 28, 35). Natomiast złoty diadem zakładany na tiarę lub mitrę miał mieć wyryty napis qodesz le-JHWH („poświęcony JHWH") (Wj 28, 36). Celem diademu było zapewnienie boskiej akceptacji modlitw Izraela oraz możliwości usunięcia grzechów. Kapłani byli konsekrowani do posługi przez nałożenie stroju (Kpł 8). Dziedziczność zaś urzędu kapłańskiego znajduje swą podstawę przy przekazaniu szat Aarona na jego syna Eleazara na górze Hor (Lb 20, 22-29). Termin określający najwyższego kapłana w języku ugaryckim wiele wyjaśnia: rb khnm, czyli inaczej jest to skrót od „największy spośród swoich braci (kapłanów)". Podobną ideę spotykamy w

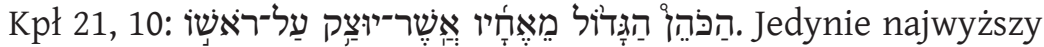
kapłan - przypomnijmy - dostępował obrzędu namaszczenia olejem (Wj 29, 7; Kpł 8, 12; 21, 10), stąd w jego określeniu pojawia się właśnie

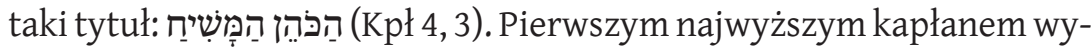
święconym na takiego jest Aaron, brat Mojżesza (Wj 28,11nn). W Dzień Przebłagania (Jom Kippur), według Kpł 16, 4 Aaron wchodził do Świętego

${ }^{15}$ Por. M. Haran, Priestly Vestments, [w:] Encyclopaedia Judaica, dz. cyt., t. 16, s. 512. 
Świętych w 4 częściach ubrania ze zwykłego lnu: płaszczu, spodniach, pasie, mitrze, jednak Mishna Joma 3, 6 twierdzi, że chodziło o biały len ${ }^{16}$.

Zgodnie z Kpł 21, 10 tylko najstarsi synowie Aarona stanowią linię przyszłych arcykapłanów. Stąd pozycja w hierarchii świętości i kultu zdeterminowana jest już od dnia narodzin i sam kapłan nie może uwolnić się z takiej swej pozycji.

\section{Błogosławieństwo kapłańskie}

Błogosławieństwo udzielane przez kapłana jest zawarte w Lb 6, 24-27 i brzmi: „Niech cię Pan błogosławi i strzeże. Niech Pan rozpromieni oblicze swe nad tobą, niech cię obdarzy swą łaską. Niech zwróci ku tobie oblicze swoje i niech cię obdarzy pokojem. Tak będą wzywać imienia mojego nad Izraelitami, a Ja im będę błogosławił". Jasnym jest tu jednak, że to sam Bóg błogosławi i prawdopodobnie zakończenie błogosławieństwa: „obdarzy pokojem” posiada znaczenie „obdarzy przyjaźnią, przymierzem" na podstawie Sdz 4, 17; Lb 25, 12; Iz 54, 10 (berit szelomi). Błogosławieństwo to było częścią kultu świątynnego. Każdego ranka i wieczora przy okazji ofiary wieczystej (tamid - w czasach Jezusa były składane dwa baranki: rano za cezara lub króla, po południu za Izraela) kapłan udzielał tego błogosławieństwa ze specjalnej platformy do tego przeznaczonej, wznosząc nad ludem ręce (Mid. 2, 6; Tam. 5, 1; 7, 2; Sot. 7, 6; Meg. 18a). W literaturze rabinistycznej to błogosławieństwo zostało nazwane nesi'at kappajim (,wzniesienie rąk“). Podczas szabatów i świąt dodatkowo takie błogosławieństwo udzielane było podczas dodatkowej na te dni ofiary. Po zburzeniu świątyni i zaprzestaniu kultu ofiarniczego błogosławieństwo pozostało głównym elementem rytuału kapłańskiego. Każdy dorosły kapłan włącza się w to błogosławieństwo, chyba że ze względu na fizyczne lub inne defekty ${ }^{17}$ jest pozbawiony takiej funkcji. Zostaje również wykluczony, jeśli posiadajakieś fizyczne deformacje albo

${ }^{16} \mathrm{~W}$ takim kontekście interesująca staje się prezentacja stroju Jezusa podczas przemienienia: Mt 17, 2: „odzienie zaś stało się białe jak światło”; Mk 9, 3: „Jego odzienie stało się lśniąco białe tak, jak żaden folusznik na ziemi wybielić nie zdoła”; Łk 9, 29: „Gdy się modlił, wygląd Jego twarzy się odmienił, a Jego odzienie stało się lśniąco białe”. To jednak stanowić będzie przyczynek do osobnego opracowania.

${ }^{17}$ Jeśli kapłan zabił kogoś, dopuścił się bałwochwalstwa, poślubił zabronioną mu prawem kobietę albo jest w stanie jakiegokolwiek odurzenia. 
nie potrafi wyartykułować słów błogosławieństwa w sposób właściwy (Ber. 32b; Meg. 24b; Ta'an. 26b). W dzisiejszych czasach błogosławieństwo kapłańskie może być wypowiadane podczas publicznej liturgii synagogalnej z obowiązkową liczbą 10 dorosłych mężczyzn i to w taki sposób, że jeśli zebrani to tylko kapłani, jedynie kilku błogosławi, pozostali zaś muszą tworzyć część błogosławionego ludu (Sot. 38b). Zwolnieni są jedynie kapłani w czasie żałoby, ale muszą opuścić synagogę, zanim kapłani zostaną wezwani do błogosławieństwa. Dzisiaj w Izraelu takie błogosławieństwo udzielane jest w każdy szabat, w Jerozolimie zaś w każdy dzień. Jeśli zabraknie kapłana, tekst ten odczytuje uroczyście hazzan, śpiewak synagogi. Kapłani muszą przed błogosławieństwem ściągnąć buty i umyć ręce w asyście lewitów przed wejściem na bimę, w tym czasie hazzan musi wygłosić modlitwę z prośbą o błogosławieństwo. Wtedy kapłani nakrywają swe głowy talitem, wyciągają ręce i kierują dłonie w stronę ludu, specjalnie układając palce do błogosławieństwa. Taki właśnie atrybut pojawia się na grobach kapłanów. Zwyczajem zaś ludzi jest nie patrzeć na błogosławiącego kapłana. W wielu wspólnotach ojciec gromadzi pod swym talitem własne dzieci na czas błogosławieństwa. Kiedy kapłani wypowiadają błogosławieństwo, odpowiada się „amen” na każdą z trzech części, jeśli wypowiada je hazzan, wówczas mówi się tylko „niech się dzieje wola Twoja”. W dzisiejszym judaimie konserwatywnym błogosławieństwo kapłańskie jest opcjonalne, zaś w judaizmie reformowanym została odrzucona idea specjalnego przywileju kapłańskiego, stąd na koniec liturgii błogosławieństwa takiego udziela rabin przewodniczacy liturgii ${ }^{18}$.

\section{Nowy Testament - nowość kapłaństwa}

Chrystusa w Liście do Hebrajczyków

Kolejnym etapem będzie zapoznanie się z terminologią kapłańską i arcykapłańską zastosowaną w odniesieniu do Jezusa w Liście do Hebrajczyków. Autor tej księgi wybrał dwa terminy, które określają

${ }^{18}$ Por. Birkat ha-Kohanim, [w:] The Oxford Dictionary of Jewish Religion, dz. cyt., s. 130-131; H. Brichto, Priestly Blessing, [w:] Encyclopaedia Judaica, dz. cyt., t. 16, s. 510; Priestly Blessing in the Halakhah, [w:] Encyclopaedia Judaica, dz. cyt., t. 16, s. 510-511; Priestly Blessing, [w:] Sara E. Karesh, Mitchell M. Hurvitz, Encyclopedia of Judaism, dz. cyt., s. 405-406. 
nową jakość kapłaństwa ze względu na fakt, że zostały zastosowane do Żyda nienależącego do rodu Aarona ani do pokolenia Lewiego ${ }^{19}$. Mowa naturalnie o Melchizedeku.

Pierwsza referencja w Hbr 2,17 mówi o podobieństwie do braci, nie ma jednak mowy o podobieństwie do synów pokolenia Lewiego. Użyty

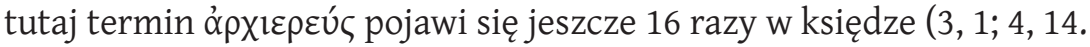
$15 ; 5,1.5 .10 ; 6$, 20; 7, 26. 27. 28; 8, 1. 3; 9, 7. 11. 25; 13, 11). Każda z tych referencji przynosi jednak nowe aspekty kapłaństwa Chrystusowego:

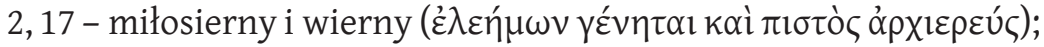

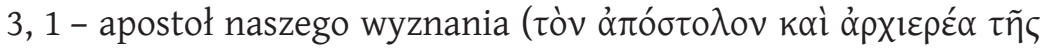

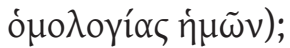

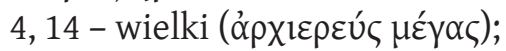

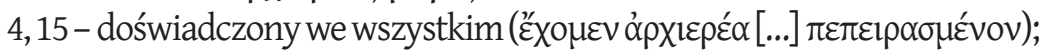

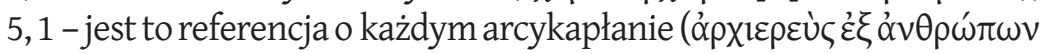
$\lambda \alpha \mu \beta \alpha v o ́ \mu \varepsilon v o \varsigma) ;$

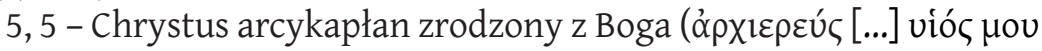

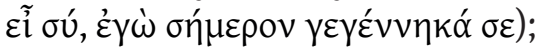

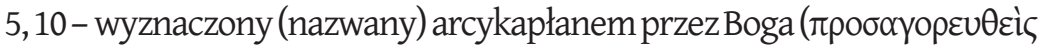

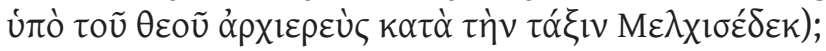

6, 20 - poprzednik, który stał się arcykapłanem na wieki na wzór

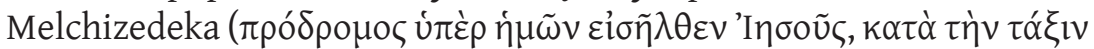

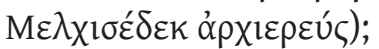

7,26 - święty, niewinny, nieskalany, oddzielony od grzeszników, wy-

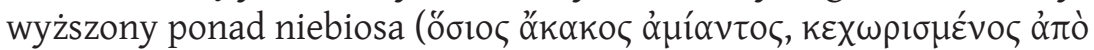

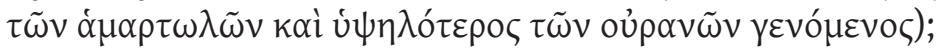

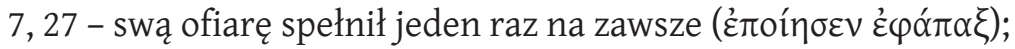

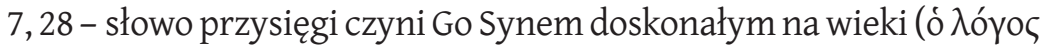

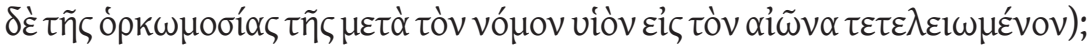

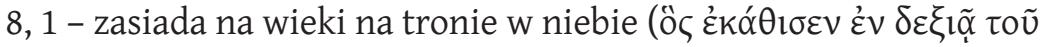

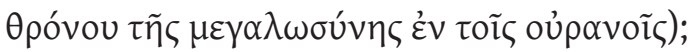

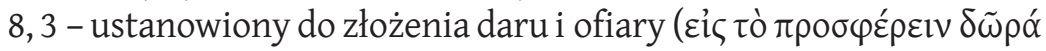

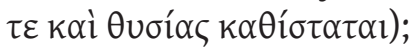

${ }^{19}$ Por. np. T. Jelonek, Problem autorstwa, Kraków 2006, s. 36-38 (List do Hebrajczyków, 1) oraz R. Bogacz, Misja Chrystusa w świetle hapax legomenów, Kraków 2006, szczególnie s. 150-163; 183-187 i 434-446 (List do Hebrajczyków, 2). 


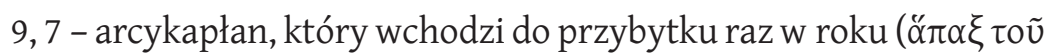

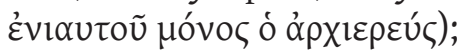

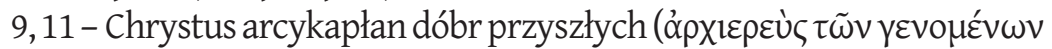
$\dot{\alpha} \gamma \alpha \theta \tilde{\omega} v)$

9, 25-26 - raz jeden składa swą ofiarę dla zgładzenia grzechów (zic

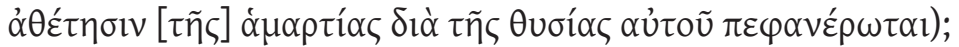

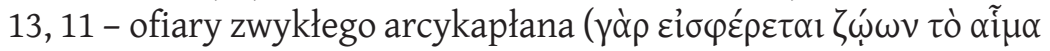

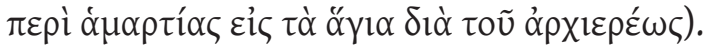

Drugim terminem określającym Chrystusa jest i iepeúc, który występuje 14 razy w Hbr: 5, 6; 7, 1.3.11. 14. 15. 17. 20. 21. 23; 8, 4; 9, 6; 10, $11 ; 10,21$. Kursywą zostały zaznaczone cytaty ze Starego Testamentu.

Oto kontekst oraz przydawki kwalifikujące ten termin:

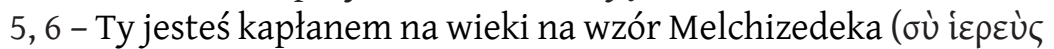

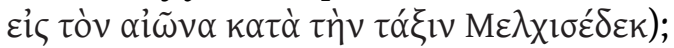

7, 1 - Ten to Melchizedek, król Szalemu, kapłan Boga Najwyższego

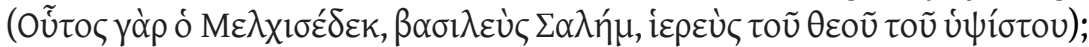

7, 3 - Bez ojca, bez matki, bez rodowodu [...] pozostaje kapłanem na

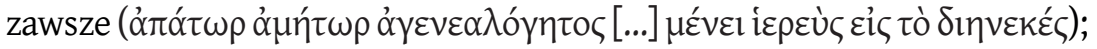

7, 11 - po co było potrzeba ustanawiać jeszcze innego kapłana na

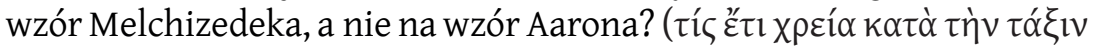

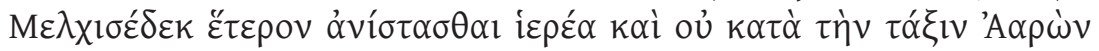
$\lambda \varepsilon ́ \gamma \varepsilon \sigma \theta \alpha \mathrm{l} ;) ;$

7, 14 - nasz Pan wyszedł z pokolenia Judy, a Mojżesz nic nie wspo-

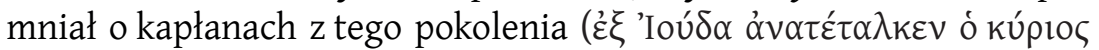

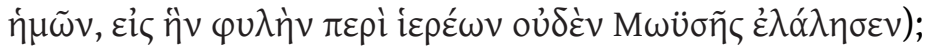

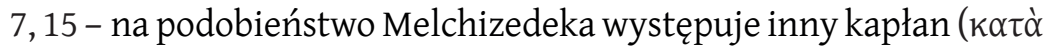

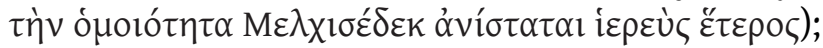

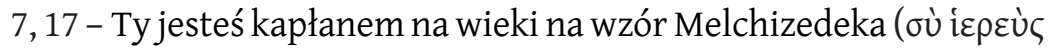

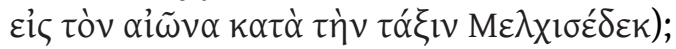

7, 20 - Gdy bowiem tamci bez przysięgi stawali się kapłanami (oi $\mu \dot{v} v$

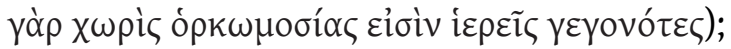

7, 21 - Poprzysiągł Pan, a nie będzie żałował: Ty jesteś kapłanem na

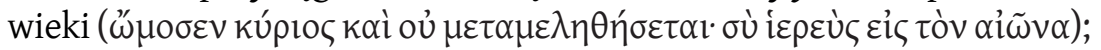

7, 23 - tamtych wielu było kapłanami, gdyż śmierć nie zezwalała

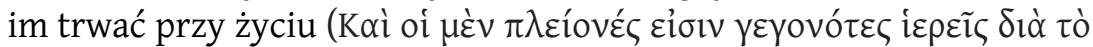

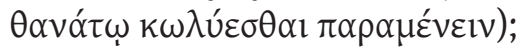


8, 4 - Gdyby więc był na ziemi, to nie byłby kapłanem, gdyż są tu inni, którzy składają ofiary według postanowień Prawa ( $\varepsilon \dot{i} \mu \dot{\varepsilon} v$ oũv

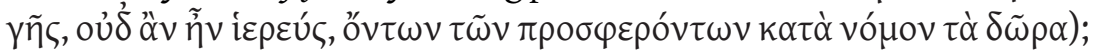

9, 6 - do pierwszej części przybytku zawsze wchodzą kapłani spra-

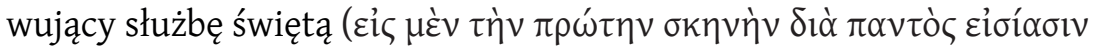

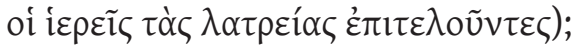

10, 11 - każdy kapłan staje codziennie do wykonywania swej służby, wiele razy te same składając ofiary, które żadną miarą nie mogą

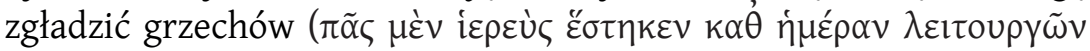

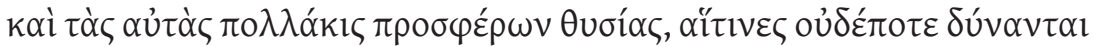

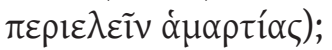

10, 21 - Mając zaś kapłana wielkiego, który jest nad domem Bożym

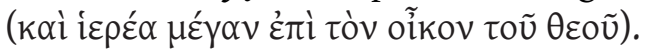

Referencje 5, 6; 7, 1.3 odnoszą się do Melchizedeka, zaś 7, 20. 23; 9, 6; 10, 11 odnoszą się do kapłanów porządku lewickiego. W sposób szczególny warto więc zwrócić uwagę na pozostałe referencje, nie zapominając jednak o terminach kwalifikujących „kapłana”. I tak Chrystus jest kapłanem podobnym do Melchizedeka, jeśli chodzi o brak odnośników do rodziców i genealogii koniecznej do wypełnienia prawa w odniesieniu do kapłaństwa lewickiego ${ }^{20}$. Chrystus został ustanowiony kapłanem, a nawet arcykapłanem mocą przysięgi Bożej. Nie potrzebuje składania codziennych ofiar, biorąc pod uwagę fakt, że nie umiera. Nie przebywa onjużw przybytku ziemskim, którego już nie ma, ale jest w niebie, które było wzorem dla przybytku ziemskiego. W odróżnieniu od arcykapłana według porządku lewickiego Chrystus nie jest odziany w jakiś szczególny strój, gdy spełnia swą funkcję arcykapłańską na krzyżu. Wręcz przeciwnie, Ewangelie odnotowują, że został pozbawiony wszelkiego odzienia. Jak więc sugerowała czy to Księga Rodzaju (przypadek Melchizedeka), czy też cytowana już Księga Ezechiela (w przypadku arcykapłana lewickiego), czy w końcu zwyczaj wypożyczania szat od Rzymian za czasów Chrystusa, szata nie wydaje się elementem konstytutywnym. Co więcej, zburzona świątynia jerozolimska, a w konsekwencji brak możliwości sprawowania kultu przez arcykapłana podkreślają rolę arcykapłana

${ }^{20}$ Por. G. Granerød, Melchizedek in Hebrews 7, „Biblica“ 90 (2009), s. 188-202, a także

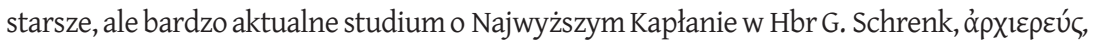
[w: Theological Dictionary of the New Testament, dz. cyt., t. 3, s. 274-282. 
Jezusa Chrystusa w wyłączności i możliwości kultycznej w przybytku niebieskim.

\section{Podsumowanie}

Studium terminologii dotyczącej arcykapłana zarówno w tekście masoreckim, jak i w LXX pozwala na wyznaczenie roli, działalności i wyjątkowości arcykapłana. Jest ona postrzegana przez pryzmat specyfiki stroju arcykapłańskiego, któremu przypisane są określone funkcje. Wyrazem godności kapłańskiej jest też specjalne błogosławieństwo. Te elementy zostały przedstawione w kontekście biblijnego judaizmu. Odmienność godności i funkcji arcykapłańskiej Jezusa Chrystusa została zaprezentowana poprzez zestawienie w dwóch grupach tekstów z Hbr. Grupy te utworzone są z dwóch terminów wspólnych z LXX: ỏpxiepeúc i i

Kraków

ROMAN MAZUR SDB

\section{Słowa kluczowe}

Arcykapłan, kapłan, szaty, błogosławieństwo, Jezus Chrystus

\section{Summary}

Jesus Christ the High Priest

Study of terms connected with High Priest, both in Masoretic Text and in the LXX, gives the possibility to present the role, activity and exceptionality of High Priest. It is seen through the specific High Priest's vestments, having particular functions. An expression of Priest's dignity is a special blessing. These elements are presented in the context of biblical Judaism. The difference of the dignity and the High Priest's function of Jesus Christ is presented by two groups of texts from Heb. The groups are

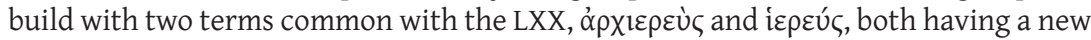
theological connotation.

\section{Keywords}

High Priest, Priest, vestments, blessing, Jesus Christ 